\title{
The Existing Problems and Analysis in the Contemporary Environmental Legal System Operation in Our Country
}

\author{
Jiong Guo \\ Lanzhou University of Arts and Science, Lanzhou, 730000, China
}

Keywords: Contemporary environmental legal system. Operation issues. Resolution strategy

\begin{abstract}
Environmental issues have attracted high attention of people. As our country is at primary level of socialism, the environmental pollution has become serious, so environmental legal system enhancement is particularly important and urgent. This article would focus on the analysis of legal construction status, elaboration on the importance and significance of contemporary environmental legal system under current social development situation. In the view of present problems in environmental legal system and management, the enquiry of how to improve the contemporary environmental legal system has been indicated. I hope perfection of strategic goal of our contemporary environmental legal system could be realized, environmental protection could be improved, and pollution problems could be controlled effectively through my analysis.
\end{abstract}

\section{Introduction}

As human production life goes deeper, environmental pollution and disruption have become more and more serious, especially in our country. The main reason is that the contemporary environmental legal system is not accountable enough for its performance, though lots of laws and regulations have been issued by government. Due to vulnerabilities existed in lots laws and regulations as well as weak enforcement of the locals, these laws and regulations are not playing a substantive role. Therefore, research and analysis in problems existed in contemporary environmental legal system is important and significant in finding problem resolution. Appropriate staff shall pay high attention to their own work, specific duties of each person, and contribute their efforts to perfect the socialism environment legal system through their intelligence and wisdom.

\section{Existing problems in contemporary environmental legal system operation in our country}

\section{Environmental legislative status}

Two main problems existed in environmental legislative status, one is imperfect the legislative system, the other one is failure meeting the expectation of legislative effect, which can be reflected in the following points:

1). With lag of legal effects and short of supportive normative writing, the update rate of environmental basic law is too slow to solve ever-changing environment problems;

2). The support of constitution is not enough, and the law is on a low level, and key issues of the definition of post-register of environmental impact assessment and regulation of public welfare litigation system are not reasonable; the legislation standard falls behind;

3). There are problems in the legislative system and central legislation is lack of public and transparency, power of modern network has not been applied to brainstorm:

Problems existed in its own institution where law enforcement officials do not value their work and the connection of dual control and management for the legislative system is not that close; what's more, there is a big gap between central and local, some contradictions existed between them.

Efforts put into environment issues related to leaders' emphasis.

Short of participation from the public. 


\section{Problems existed in execution of environmental protection and supervision}

Law enforcement system shall include two aspects that are power allocation for horizontal and organization establishment for vertical, whereby the environmental enforcement, subject of enforcement and power allocation are key points. At present, the supervision of environmental protection legal system is not strong enough. Although several supervision departments have been set, staff from these departments are not fulfilling their duties in daily enforcement; in the mean time, vulnerabilities could be found in management system, especially in lax enforcement supervision system, such as mineral products, land and agriculture . Major defaults of environmental enforcement system are organization establishment for vertical and power allocation in environmental enforcement authority.

In the aspect of central environmental protection enforcement system, the connection of our contemporary legal system with loopholes inside is unscientific, which makes the enforcement difficult, and this ends with vulnerabilities environmental protection enforcement system. In addition, cross conflict might exist in different legal systems, and the internal friction of government would be serious, which has significant affect on environmental protection judicial efficiency. By the way of law enforcement of central environmental protection enforcement system, the phenomenon of substitute the party for the government, no distinguish between political and parties, and replace the judicial with parties are common.Local law enforcement system has following problems:

Liability system of law enforcement officials inadequate, assessment of personal responsibilities is not strict;The problem of local environmentalism widespread, effects of administrative intervention to environmental protection department stands out;Authority of environmental protection enforcement is weak, so the result is not satisfactory;Exercise power of primary sector is too weak to play its due role.Due to undefined obligation of environmental protection enforcement officials, slack law enforcement could be pointed out.

In recent years, our country keeps working on aggressive investigations on supervision system, and set up six supervision centers to monitor the environmental enforcement. However, with the higher power of supervisions, local law enforcement would be limited. As a concept unit, the law enforcement system does not have the fundamental transformation, so there would not be much developed in environmental enforcement.

\section{Problems existed in environmental production judicial departments}

Compared to administrative legislation, the construction of environmental protection judiciary is not in place. This would result in difficulties in local environmental protection enforcement and practical implementation of environmental protection laws. As illegal activity appears constantly, and civil rights are full of obstacles, social contradiction would be caused. Major defaults found in implantation of environmental protection judiciary are:inattention on proceedings by litigant;accreditation difficulties, acceptance difficulties, and implementation difficulties; administrative penalty instead of criminal punishment

With improvement of professional standards, construction of environmental protection court shall be enhanced gradually and reform process of judicial environment could be promoted. Yet to implementation of environmental protection court has been made hard by "hollow reputation without basis", "no case to be handled".

\section{Causes analysis of problems existed in contemporary environmental legal system operation in our country}

\section{Causes for legislation aspect}

There are three influencing factors in environmental legal system evils: efficiency supremacy principle, individual undeveloped and historical factor, which conducted by comprehensive reasons of evasiveness, lack of public engagement, super leading role of government, and policy highlight.

Administration organs of China and other agencies are in a relationship of advocate complementary, which means that administration organs could participate in social relationship to implement its administrative actions with obvious advantages; and this is main cause of executive 
dominance. The essence of individual administration is social acquaintance within political rights, which makes wrangling evasiveness and departments' benefits keep emerging. Therefore, with such circumstance, it is inevitable to have problems existed in environmental legislative process.

\section{Causes for judiciary, enforcement and technique}

For historical reasons, China has been affected greatly by ritual, righteousness and authoritarianism, and standards and transparency cannot be completely conducted during implementation. Obedience to authority is result of strong Chinese cultural gene basis, when disputes existence, people are like to have acquaintance involved. More seriously, internal of environmental protection department has the same problem; nepotism would affect the acting by law for related law enforcement officials and fairness of legal system. It can be seen that the game among legal system, emotions, legal sense and personal authority is various with subject role, and it is the main cause to impede environmental enforcement and affect judiciary function.

\section{Causes for public participation}

The participation of public in environmental legal system establishment would be affected by their subjective state of mind and environmental culture acknowledgement of government. When it comes to macro topics, environmental value would always be overlook, the government would automatically look at the issue from supervision side. It the view of this, the participant of public might be connected with "quality issues". While the promotion effect of public to environmental value ignored, the government may lay stress on the imagery of mass incidents, and the situation arisen by democracy might be addressed.

\section{Importance of enhancement of contemporary environmental legal system construction in our country}

Enhancement of contemporary environmental legal system construction in our country is important and significant, as the environmental pollution in our country is heavy. China has a vast field with different local legal systems; we have not built a uniform system in environmental protection. What' more, as issues come up in weak enforcement, many actions on environment pollutions could not be controlled. Hence, enforcement of contemporary environmental legal system would have an important role, which could be played by social environment guarantee and emissions reducing, and only under the restraint of legal system, polluting industries and humans would pay high attention to .environmental pollution issues. By strict legal system, people's moral sense and behavior would be controlled obviously. Major part of environmental pollution in our country is the development of heavy industry, and it can be reduced by proper management. Therefore, in future legal system construction, screening for industrial emission shall be addressed, and direct emission of pollution gas and contaminant shall be controlled strictly. In a word, environmental legal system construction is an important way to control environment pollution.

\section{Strategy of perfect contemporary environmental legal system in our country}

\section{Environmental impact institution establishment}

Under the background of information age, supervision of network shall be capitalized fully on environmental protection system construction to establish an environmental impact assessment system. Due to absence of supervision power, enforcement of environmental legal system construction is weak. As the environmental protection is a matter of entire society concern, supervision of the masses is required. With the number of Chinese netizens increasing, attentions on environmental protection and environmental legal system construction are getting more and more. And while clearing up the legal system, establishment of environmental impact legal system guarantees environmental legal system operation improvement. The target of environmental impact protection system shall be identified to improve the techniques of environmental assessment. The public communication platform shall be established through internet for anonymous report on illegal 
actions. Besides, the reviewers shall summaries public comments to match award and punishment system and handle issues with discretion.

\section{Improvement of environmental protection target-oriented responsibility system}

Subject of environmental protection target-oriented responsibility system is based on planning. According to location differences, a uniform environmental protection legal system would be established and improved. Related department officials shall take pollution declaration registration work, especially for production activities of enterprises that need to be managed and supervised specifically. These enterprises are required to handle pollution discharge cautiously and introduce advanced equipments. In the end, with the efforts of competent department staff and system of mutual monitoring, supervisory control could be conducted on all illegal activities against environmental protection laws and regulations.

\section{Environmental protection planning system establishment}

Environmental planning indicates that the action plan and overall scheme for environmental work could be implemented by environmental target set in a certain time. The planning is an important part of social development plan and national economy, and it is also an important way to reflect the coordinated development of environmental protection and economic society. Environmental protection planning system is an experience summarized from passive management of environmental pollution by western countries, and it is a comprehensive method that can get at the root of the problem. The environmental protection planning system includes natural ecological protection, pollutant emission and governance, urban environment quality control, etc. Resulted from scientific decision and environmental forecast, the planning plays an important role in our environmental legislation process. Hence, through a serious of measures, our social environmental protection legal system could be improved, and the loopholes would be reduced; the enforcement of environmental protection legal system could be enhanced and efficiency supervision and management would be realized. By comprehensive construction of "Two-oriented society" of our socialism and achievement of permanent healthy development of society would conduct the harmonious sustainable development between man and nature.

\section{Conclusion}

In conclusion, it is important and significant to protect our environment, and this is a key issue to be resolved to construct the socialism with Chinese characteristics, and also is prerequisite and guarantee for construction of "Two-oriented society" of our socialism. As for the issues of imperfect environmental protection legal system, I think the construction of environmental laws and regulations shall be enhanced, and we shall be brave to admit our shortcomings in present system; we also need to enhance the investigation with deep analysis to find solutions and formulate feasible legal system to improve related systems. There is no time to delay to construct and perfect our socialist legal system; related department staff shall study it seriously to put efforts in construction of socialist environmental protection legal system.

\section{References}

[1] Wang Jin, Review and Survey on China's Rule of Environmental Law in Past 30 Years, Journal of China University of Geosciences (Social Sciences Edition), 2009 (05).

[2] Huang Xisheng, Wang Jiang,Difficulties and Solutions to China Environmental Enforcement, Journal of Chongqing University (Social Sciences Edition), 2009 (01).

[3] Gong Gu, Public Participation Shall Be Enhanced in Environmental legislation, Environmental Protection, 2011 (07).

[4] Wang Yajing,"National Environmental Education Forum 2009 - Pollutants Discharge Reduction Improved by Public Participation” Held in Beijing, Environmental Education, 2009 (08). 
[5] Discussions on Prominent Problems of Environmental Enforcement Difficult at Primary Level, Shang Lin, Environmental Science Survey, 2012 (03).

[6] Liu Feng, Su Hongzhi, A Brief Analysis of Existing Problems and Solutions to Environmental Enforcement, Environmental Science Survey, 2012 (04)

[7] Qin Tianbao, Sublation of “Technical Rationality” and Flyback to Ethical Negotiations - Prospect of Global Climate Negotiation Law Mode Under the Background of Knowledge of Science and Technology, Journal of China University of Geosciences (Social Sciences Edition), 2012 (02)

[8] Zhang Yuqing, Du Qun, Legal Protection of Environmental Services Contract - In the View of Internalization of Enterprise Environmental Responsibility, Research on Rule of Law, 2013 (08). 